\title{
THE ANALYSIS TOWARD FACTORS THAT AFFECT SALES WORK PERFORMANCE AMONG INSURANCE AGENTS OF PT. SINAR MAS BOGOR
}

\author{
Sunardi*, Saleh Muhamad Akbar, Almia \\ Faculty of Economics and Business, University of Persada Indonesia, Indonesia \\ ${ }^{*}$ E-mail: ranggaone2003@yahoo.com
}

\begin{abstract}
This study aims to determine the effect of organizational customer orientation towards customer orientation, and also examined the effect of environmental sales condition on adaptive selling, as well as the influence of consumers' orientation and adaptive selling on insurance agent performance. The study was conducted on 37 insurance policy agents at PT. Asuransi Sinar Mas in Bogor. The analysis used Partial Least Square (PLS). The results showed that the organizational customer orientation has significantly positive effect on consumer orientation. Environment sales conditions also have positive significant effect on adaptive selling. In addition, consumer orientation and adaptive selling also have significantly positively effect on the salespersons performance.
\end{abstract}

\section{KEY WORDS}

Organizational customer orientation, customer orientation, environmental sales conditions.

The tight competitions between companies has demanded the salesmen to develop some competitiveness points through relational approach more intensively, thus the business will be continuously developed. That is why the companies must be able to transform their salesman to be adaptive. Roman, S. and lacobucci, D. (2010) states that the effectiveness of adaptive sales is effects by the working environment. Meanwhile, according to Rentz et al. (2002) salesman must be able to filter some sales techniques that will be use later on the field, thus it will be easier for them to adapt with the environment and condition of market. That is why the implementation of adaptive sales is effects by the working environment.

Another factor that affects the working performance of salesman is customer orientation and customer oriented selling. the characteristic of customer orientation sales which is implemented by some companies are keep in good touch with the customers, diagnose the customer's need, trying to build long term relationship with customers, and overcome the problems which has something to do with the quality of product and services from companies (Flaherty et al., 2001). Brasher et all (2007) firmly stated that customer orientation is learned behavior which is affected by environment factors, which is adapted during several times. The organization custom helps to develop the behavior and attitude of sales performance (Rozell et al., 2003). That is why the culture of companies who applies customer orientation is in positive outcome within customer orientation approach.

The salesman who applies customer orientation will create plus points that will give more attraction in product offer and become a strong candidate of predictor for future market (Franke and Piller, 2004). This method is already proven by support in cross buying, customer maintenance, and affect direct buying (Dean, 2007).

In insurance market, the human resource is one of important aspect where the companies are must to be able to manage the resource more effective in other to compete with other companies. Because, insurance is one of company type who use services which is very crucial in attracting more customers. The business is very prospective market, and the potential markets are still lots of variety, thus, it will give a long term benefit for the company. The development of macro business that contributes in nation's income for society is one of indication that shows increasing demand of insurance use among society. In summary, the ability of company to attract new customer and maintain the old one will be an important barometer for insurance company. 


\section{METHODS OF RESEARCH}

The study belongs to one of casual research, because the research problems stated in the paper is the result of previous studies that needs for supports, examination, and development of conceptualization from the latest facts (Ferdinand, 2006). The data collection technique is using questionnaire. The series of questions has connection with the organizational customer orientation, market's environment, customer orientation, adaptive sales, and salesman working performance. The indications of customer oriented organization environment is taken from Cross et all (2007) within 6 indicators, the indication of sales environment is taken from Franke and Park (2006) within 3 indicators, the customer orientation indications is taken from Cross et all (2007) within 10 indicators, the indications of adaptive sales is taken from Franke and Park (2006) within 5 indicators, and the salesman performance indicators are taken from Cross et all (2007) within 5 indicators.

The respondents of research consist of 37 insurance agents of Sinar Mas Bogor. The questionnaire is handed directly to them. The scale used in this experiment is Likert scale within 5 levels. The analysis techniques in this study is Partial Least Square which is component based predictive model within variance based approach or component based. it means that the data must not meet the ideal criteria, which has not estimated the scale, data distribution, and total sample. In the PLS analysis, it does not require big data assumption, the data must be normal multivariate distributed, and must meet the determinacy condition (Ghozali, 2008:4).

\section{RESULT OF STUDY}

According to the 37 respondents, the sex of respondents are dominated by male which is 27 men or $72,97 \%$, which contains most of $30-40$ years old people or $56,76 \%$. The level of education among respondents are dominated by bachelor degree which are 78 people or $56,12 \%$. On one hand, most of respondents have served the company for approximately 3 to 4 years of working which are 19 people or $51,35 \%$.

Table 1 - Statistic Description

\begin{tabular}{|c|c|c|}
\hline Variable & Average & Deviation Standard \\
\hline $\mathrm{X}_{1}$ & 3,79 & 0,53 \\
\hline $\mathrm{X}_{2}$ & 3,81 & 0,61 \\
\hline $\mathrm{Z}_{1}$ & 3,71 & 0,57 \\
\hline $\mathrm{Z}_{2}$ & 3,71 & 0,64 \\
\hline $\mathrm{Y}$ & 3,69 & 0,73 \\
\hline
\end{tabular}

The descriptive statistic shows in the table 1 that the average number of organizational customer orientation is 3,79 within deviation standard of 0,53 , it shows the variation of organizational customer orientation which is $14,03 \%$. The average value of sales environment is 3,81 within 0,61 deviation standard, it shows the variation of sales environment about $16,04 \%$. The average value of customer orientation is 3,71 within 0,57 deviation standard, it shows the variation of customer orientation about $15,44 \%$. the average value of adaptive sales is 3,71 within 0,64 deviation standard, it shows the variation of adaptive sales about $17,23 \%$. The average value of salesman working performance is 3,69 within 0,73 deviation standard, it shows the variation of salesman working performance about $19,85 \%$.

The result of convergent validity analysis, shown in table 2 , it stated that all declaration items for each variable is valid as it possesses above 0,7 loading factor value.

The result of discriminant validity examination by comparing the square root of Average Variance Extracted (AVE) for each construct to another. The model results in consistent value within convergent validity test in previous step. The construct root of AVE variable is indicated in bold number, it shows the higher value than construct variable correlation to other variables. 
Table 2 - The Outer Loading Value

\begin{tabular}{|l|l|c|}
\hline \multicolumn{1}{|c|}{ Variable } & & Loading \\
\hline Customer & Factor \\
Orientation & Develop the commitment toward customer. & 0,8294 \\
Working & Provide valuable product to customer. & 0,8844 \\
Environment & Understand the customer expectation. & 0,9121 \\
$\left(\mathrm{X}_{1}\right)$ & Fulfill the customer satisfaction. & 0,7928 \\
& Provide product's prototype. & 0,8366 \\
\hline Sales & Measure the customer satisfaction. & 0,8073 \\
\hline Environment & The needs and customer type. & 0,9260 \\
$\left(\mathrm{X}_{2}\right)$ & Sales situation type. & 0,9031 \\
\hline Customer & Products provided by company. & 0,7876 \\
Orientation $\left(Z_{1}\right)$ & Help the customers to find his objective. & 0,8262 \\
& Help the customers to find his objective by giving satisfaction. & 0,8231 \\
& Reveal the customer expectation. & 0,8165 \\
& Help customer discussing the needs. & 0,8199 \\
& Provide customer with information and not oppression. & 0,8305 \\
& Help customer finding the expected products. & 0,8251 \\
& Offer the proper and expected products to the customers. & 0,8496 \\
& Answer the questions from customer. & 0,8297 \\
& Provide customers with good argument to help them make a better decision. & 0,8260 \\
& Provide customer with precise data about the products. & 0,8189 \\
\hline Adaptive Sales & Use different approaches techniques for different customers. & 0,9299 \\
$\left(Z_{2}\right)$ & Interchange the approaches technique during interaction with customers. & 0,8934 \\
& Reveal the information about customer in order to give them with proper needs. & 0,7906 \\
& Effectively interchange the presentation. & 0,8633 \\
& Must be sensitive toward customer need. & 0,7212 \\
\hline Sales Working & The quantity target. & 0,8488 \\
Performance & The ability to achieve the target. & 0,8913 \\
$(Y)$ & The quality of sales working performance related to relationship with customers. & 0,8406 \\
& The quality of sales working performance related to time, cost, and planning & \\
& management. & 0,9094 \\
& The quality of sales working performance related to knowledge about customer & \\
& background. & 0,9546 \\
\hline
\end{tabular}

Table 3 - The AVE Root Comparison with Latent Variable Correlation

\begin{tabular}{|l|c|c|c|c|c|}
\hline \multicolumn{1}{|c|}{ Variable } & $\mathrm{X} 1$ & $\mathrm{X} 2$ & $\mathrm{Y}$ & $\mathrm{Z} 1$ & $\mathrm{Z} 2$ \\
\hline Customer Orientation Working Environment $\left(\mathrm{X}_{1}\right)$ & 0.8448 & 0 & 0 & 0 & 0 \\
\hline Sales Environment $\left(\mathrm{X}_{2}\right)$ & 0.5625 & 0.8744 & 0 & 0 & 0 \\
\hline Sales Working Performance $(\mathrm{Y})$ & 0.2297 & 0.53 & 0.8899 & 0 & 0 \\
\hline Customer Orientation $\left(\mathrm{Z}_{1}\right)$ & 0.558 & 0.6435 & 0.7108 & 0.8266 & 0 \\
\hline Adaptive Sales $\left(\mathrm{Z}_{2}\right)$ & 0.2303 & 0.5872 & 0.8034 & 0.5714 & 0.8430 \\
\hline
\end{tabular}

Source: The result of PLS analysis.

Discriminant validity can also be seen in the cross loading value between the indicator and the construct. It can be seen that the correlation of consumer-oriented organizational environment $\left(X_{1}\right)$ with the indicator is higher than the correlation of consumer-oriented organizational environment indicator $\left(X_{1}\right)$ with sales environment construct $\left(X_{2}\right)$, consumer orientation $\left(Z_{1}\right)$, adaptive sales $\left(Z_{2}\right)$, and salesman performance $(Y)$. This also applies to the other four variables, which indicate that the latent construct predicts the block indicator better than the other block indicators. The results can be seen in Table 4.

The result of reliability test within composite reliability analysis is displayed on table 5 , it shows that each research variables has composite reliability over 0,70 . thus, it could be concluded that each variable possessed good reliability.

The result of structural model is displayed on table 6 . the coefficient path test is performed by comparing the $t$ table value on significance level of $5 \%$, it is about 1,96 . If the $t$ statistic value is higher than t table value which is 1,96 , the coefficient path is certainly significant. According to the structural model, it could be concluded that the customer oriented organization $\left(X_{1}\right)$ is positively significant affected toward customer orientation $\left(Z_{1}\right)$, the sales environment $\left(X_{2}\right)$ is positively significant affected toward adaptive sales $\left(Z_{2}\right)$, 
customer orientation $\left(Z_{2}\right)$ is positively significant affected toward salesman work performance $(Y)$, and adaptive sales is positively significant affected toward salesman work performance $(Y)$.

Table 4 - Cross Loading Factor

\begin{tabular}{|c|c|c|c|c|c|}
\hline Indicator & $\mathrm{X} 1$ & $\mathrm{X} 2$ & $\mathrm{Y}$ & $\mathrm{Z1}$ & $\mathrm{Z} 2$ \\
\hline $\mathrm{X} 1.1$ & 0.8294 & 0.3317 & 0.0922 & 0.3386 & 0.1031 \\
\hline $\mathrm{X} 1.2$ & 0.8844 & 0.4701 & 0.2063 & 0.5052 & 0.1911 \\
\hline $\mathrm{X} 1.3$ & 0.9121 & 0.5119 & 0.2209 & 0.4862 & 0.245 \\
\hline $\mathrm{X} 1.4$ & 0.7928 & 0.3411 & -0.0111 & 0.3179 & -0.0771 \\
\hline $\mathrm{X} 1.5$ & 0.8366 & 0.4878 & 0.097 & 0.3598 & 0.1313 \\
\hline $\mathrm{X} 1.6$ & 0.8073 & 0.5895 & 0.3745 & 0.6449 & 0.3779 \\
\hline $\mathrm{X} 2.1$ & 0.4302 & 0.926 & 0.4937 & 0.5601 & 0.5545 \\
\hline $\mathrm{X} 2.2$ & 0.4976 & 0.9031 & 0.5514 & 0.6058 & 0.5172 \\
\hline $\mathrm{X} 2.3$ & 0.5631 & 0.7876 & 0.3329 & 0.5222 & 0.4643 \\
\hline $\mathrm{Y} 1$ & 0.1683 & 0.3962 & 0.8488 & 0.6109 & 0.6005 \\
\hline $\mathrm{Y} 2$ & 0.2036 & 0.5148 & 0.8913 & 0.699 & 0.6954 \\
\hline $\mathrm{Y} 3$ & 0.1917 & 0.5554 & 0.8406 & 0.6395 & 0.7641 \\
\hline $\mathrm{Y} 4$ & 0.2662 & 0.4472 & 0.9094 & 0.5901 & 0.7166 \\
\hline $\mathrm{Y} 5$ & 0.1911 & 0.4327 & 0.9546 & 0.6192 & 0.78 \\
\hline $\mathrm{Z1.1}$ & 0.4535 & 0.5076 & 0.5782 & 0.8262 & 0.577 \\
\hline $\mathrm{Z1.2}$ & 0.2819 & 0.4009 & 0.5983 & 0.8231 & 0.4264 \\
\hline $\mathrm{Z1.4}$ & 0.3688 & 0.439 & 0.5609 & 0.8165 & 0.4402 \\
\hline $\mathrm{Z1.5}$ & 0.4516 & 0.6133 & 0.5431 & 0.8199 & 0.4521 \\
\hline $\mathrm{Z1.6}$ & 0.4329 & 0.5234 & 0.7259 & 0.8305 & 0.5021 \\
\hline $\mathrm{Z1.7}$ & 0.5894 & 0.4635 & 0.5408 & 0.8251 & 0.4919 \\
\hline $\mathrm{Z1.8}$ & 0.6337 & 0.6402 & 0.5735 & 0.8496 & 0.5235 \\
\hline $\mathrm{Z1.9}$ & 0.5151 & 0.5173 & 0.5365 & 0.8297 & 0.3604 \\
\hline $\mathrm{Z1.10}$ & 0.4644 & 0.642 & 0.6188 & 0.826 & 0.4578 \\
\hline $\mathrm{Z2.1}$ & 0.3546 & 0.5398 & 0.5854 & 0.8189 & 0.4739 \\
\hline $\mathrm{Z2.2}$ & 0.2891 & 0.5898 & 0.8404 & 0.5543 & 0.9299 \\
\hline $\mathrm{Z2.3}$ & 0.2342 & 0.574 & 0.7548 & 0.5496 & 0.8934 \\
\hline $\mathrm{Z2.4}$ & 0.242 & 0.4511 & 0.5423 & 0.3923 & 0.7906 \\
\hline $\mathrm{Z2} .5$ & 0.0384 & 0.4967 & 0.6499 & 0.5334 & 0.8633 \\
\hline & & 0.3012 & 0.53 & 0.3268 & 0.7212 \\
\hline
\end{tabular}

Table 5 - The Result of Composite Reliability and Cronbach Alpha

\begin{tabular}{|l|c|c|}
\hline \multicolumn{1}{|c|}{ Variable } & Composite Reliability & Cronbach Alpha \\
\hline Customer Orientation Working Environment $\left(\mathrm{X}_{1}\right)$ & 0.9372 & 0.9214 \\
\hline Sales Environment $\left(\mathrm{X}_{2}\right)$ & 0.9065 & 0.8435 \\
\hline Sales Working Performance $(\mathrm{Y})$ & 0.9500 & 0.9337 \\
\hline Customer Orientation $\left(\mathrm{Z}_{1}\right)$ & 0.9557 & 0.9485 \\
\hline Adaptive Sales $\left(\mathrm{Z}_{2}\right)$ & 0.9241 & 0.8971 \\
\hline
\end{tabular}

Source: The result of PLS analysis.

Table 6 - The Examination of Coefficient Significance Path Structural Model

\begin{tabular}{|c|c|c|c|}
\hline Relation & Coefficient path & $t$ statistics & Note \\
\hline $\mathrm{X}_{1} \rightarrow \mathrm{Z}_{1}$ & 0.5580 & 6.3696 & Significant \\
\hline $\mathrm{X}_{2} \rightarrow \mathrm{Z}_{2}$ & 0.5872 & 4.8267 & Significant \\
\hline $\mathrm{Z}_{1} \rightarrow \mathrm{Y}$ & 0.3739 & 2.4091 & Significant \\
\hline $\mathrm{Z}_{2} \rightarrow \mathrm{Y}$ & 0.5898 & 5.0143 & Significant \\
\hline
\end{tabular}

According to Hair et all (2014), generally the $R$ value is 0,$75 ; 0,50$; or 0,25 the endogen construct could be described respectively as substantial, moderate, and weak affection. The $R^{2}$ Value for customer orientation variable $\left(Z_{1}\right)$, adaptive sales $\left(Z_{2}\right)$ and salesman work performance $(Y)$ are 0,$3114 ; 0,3449 ; 0,7396$. The customer orientation $\left(Z_{1}\right)$, adaptive sales $\left(Z_{2}\right)$ and salesman work performance $(Y)$ shows moderate affection. 


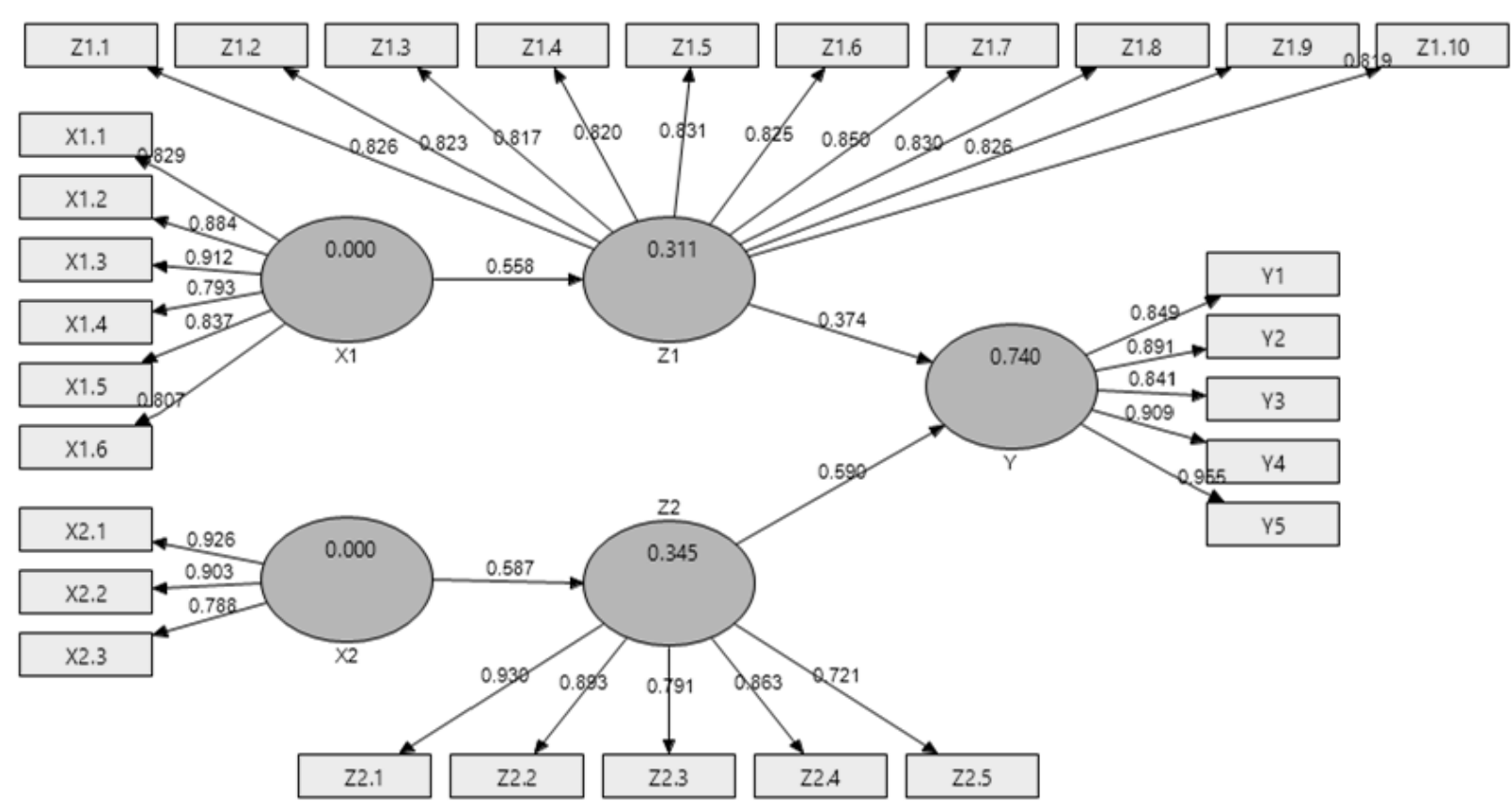

Figure 1 - The result of Partial Least Square analysis

The $R$ Square $\left(R^{2}\right)$ value and stone geyser $\left(Q^{2}\right)$ for each endogen construct is displayed on table 7 .

Table 7 - The value of $R$ Square $\left(R^{2}\right)$ and Stone-Geisser $\left(Q^{2}\right)$

\begin{tabular}{|c|c|c|}
\hline Endogen variable & $\mathrm{R}^{2}$ Value & $\mathrm{Q}^{2}$ Value \\
\hline Customer Orientation $\left(\mathrm{Z}_{1}\right)$ & 0,3114 & 0,2072 \\
\hline Adaptive Sales $\left(\mathrm{Z}_{2}\right)$ & 0,3449 & 0,2395 \\
\hline Sales Working Performance $(\mathrm{Y})$ & 0,7396 & 0,5798 \\
\hline
\end{tabular}

The $Q^{2}$ value which is higher than zero $(0)$ shows path model predictive relevance for the corresponding construct. The Stone-Geisser value $\left(Q^{2}\right)$ for customer orientation $(Z 1)$, adaptive sales $(Z 2)$ and salesman work performance $(Y)$ are 0,$2072 ; 0,2395 ; 0,5798$. as those Stone-Geisser value are higher than zero, it means that the model possessed predictive relevance for each construct.

\section{DISCUSSION OF RESULTS}

According to the results of the analysis, it can be concluded that the path coefficient is positive with a $t$ value of $6.3696>t$ table value of 1.96 , this indicates that the consumeroriented organizational environment $\left(X_{1}\right)$ has a positive significant effect on consumer orientation $\left(Z_{1}\right)$. Therefore, the first hypothesis which states that the environment of consumer-oriented organization (organizational customer orientation) has a significant positive effect on the orientation of consumer salesmen is accepted.

The consumer-oriented organizational environment will make consumers feel comfortable because they feel cared for. This will have a positive effect on insurance agents in making a better approach to consumers. Your insurance agent will feel comfortable working, because they are supported by a climate and a consumer-oriented corporate culture. This supports the study of Cross et al. (2007) which shows that organizational consumer orientation or consumer orientation environment has a significant effect on consumer orientation. This result is also consistent with the opinion of Stock and Hoyer (2005), that sales people who adopt consumer orientation are the result of organizational and marketing management practices that also focus on consumer orientation. 
Second, According to the result of analysis, it is revealed that the path coefficient value is positive within $2,4091 \mathrm{t}$ value which is higher than 1,96 . This shows that the customer orientation $\left(Z_{1}\right)$ is positive significant affected toward the salesman work performance $(Y)$. That is why, the second hypothesis stated that the customer orientation from salesman is positively affected toward the work performance is accepted.

If an insurance salesman is willing to collect the customer demand and help them to discuss of what they need, the agent will earn a good relationship with customers. It will help the agent to offer appropriate products and bale to sell the products within high quantity. This result supports the cross et all research (2007) and Srinada (2003) who state that the salesman resource is able to increase sales expectation through approach that has customer orientation principles. Franke and Piller (2004) the salesman who has customer orientation is able to identify and satisfy the customer's expectation. The same result is also declared by Dean (2007), he stated that the customer orientation approach will able to increase the sales volume through the cross-buying possibility.

Third, According to the result of analysis, it is revealed that the coefficient path has positive value within $4,8267 \mathrm{t}$ statistic value, it is higher than the $t$ table which is 1,96 . It shows that the sales environment $\left(\mathrm{X}_{2}\right)$ is positive significant affected toward adaptive sales $\left(Z_{2}\right)$. Thus, the third hypothesis stated that sales environment contribute positive effects toward adaptive selling performed by salesman, is accepted.

The different situation will make the salesman to change its strategy to deliver the information toward customers by using different approaches. The insurance agent will also change the presentation within different variations based on the number of products provided by the company. The varieties of product offering will guide the salesman to fulfill the expectation of the customers. The agent will be able to diagnose the problems faced by customers and the varieties of product offering will help them to find solution above what customers expected to receive.

The result supports Irianti's research which stated that the varieties and knowledge amount the details of product, the selling environment also plays important role in order to increase the selling rate. In consistency with the opinion from Franke and Park (2006), that the product's varieties will help the salesman to provide more options to the customer to fulfill their expectations. Giacobbe (2006), also stated that the characteristics of selling environment which is connected with customer expectation, sales situation types, and sold products plays important role on the economic wheels.

Last Result, according to the analysis, it could be shown that the coefficient path has positive value within $t$ statistic value about 5,0143 which is higher than the table principles, 1,96. It shows that the adaptive selling $\left(Z_{1}\right)$ give positive significant impact towards the work performance of the salesman agents $(Y)$. That is why, this hypothesis stated that the adaptive selling give positive significant impact towards the work performance of salesman, is accepted.

The result support Irianti's study (2008) and Srinanda (2003) who stated that the service orientation affects the work performance. Meanwhile, Keillor et all (2000) also stated that successful salesman are those who able to adapt the communication style while performing interaction with customers. In consistency with Roman and lacobucci (2010), he stated that the adaptive selling is conceptualized as smart working where the salesman is able to identify the varieties of selling situation in order to implement the correct selling approaches.

\section{CONCLUSION AND SUGGESTIONS}

Based on the result and discussion of study, there are several conclusions as follow:

- The more conducive environment organization in supporting the expectation of the customers, the better ability of customer orientation approach which is performed by the salesman.

- The better ability of customer orientation approach which is performed by the salesman, the better quality and quantity of salesman work performance. 
- The more support towards selling environment, the more adaptive salesman will be in transaction as the companies possesses effective resource in transaction process.

- The more salesmen who are adaptive to sell the products, the better choice in determining proper communication style while interacting with customer. Thus, the productivity and working performances will be higher as well.

And there are several managerial implication that could become suggestions of the study, they are:

- The companies need to hold a gathering, it is an event for the customers to build relationships or introduction or offering to new products or special products. By inviting the potential customers periodically, the companies must involve salesman to get better understanding with customers. Thus, it will increase the selling with customer orientation.

- The company needs to hold continuing workshop or training for the salesman, it will train them to be more sensitive and understand the market situation that must be faced every day. The training will focus on the special products in order to explore more markets.

- Company must provide continuing Focus Group Discussion in every unit, it is discussion about the practice of sales in markets within significance situation, and thus the sales man will have several options to improve their working performance through peer co-workers discussion.

- Company needs to build integrated working environment in order to give positive impact for the salesman, create the productive atmosphere in the office. Thus, there will be a good communication among salesmen without being ego, they must share the information about how to handle the customers about administration process, and the product's benefit, or even the competitors.

\section{REFERENCES}

1. Ahearne, M., Jelinek, R., and Jones, E. (2007). Examining The Effect of Salesperson Service Behavior in A Competitive Context. Journal of The Academy Marketing Science, 35:603-616.

2. Cross, M.E., Brashear, T.G., Rigdon, E.E., and Bellenger, D.N. (2007). Customer Orientation and Salesperson Performance. European Journal of Marketing. Vol. 41, No. 7/8, 821-835.

3. Dean, A.M. (2007). The Impact of the Customer Orientation of Call Center Employees on Customers' Affective Commitment and Loyalty. Journal of Service Research. 10(2), 16173.

4. Ferdinand, A. (2006). Metode Penelitian Manajemen. Edisi Kedua. Badan Penerbit Universitas Diponegoro. Semarang.

5. Flaherty, T. B., Dahlstorm, R., and Skinner, S. J. (2001). Organization Values and Role Stress as Determinants of Customer-Oriented Selling Performance. Journal of Personal Selling and Sales Management, Vol. XIX, No. 2 (Spring).

6. Franke, N. and Piller, F. (2004). Value Creation by Toolkits for User Innovation and Design: The Case of the Watch Market. Journal of Product Innovation Management. 21 (6), 401-415.

7. Franke, G.R., and Park, J. (2006). Salesperson Adaptive Selling Behavior and Customer Orientation: A Meta-Analysis. Journal of Marketing Research. Vol. XLIII. November:693702.

8. Giacobbe, R.W., Jackson, D.W., Crosby, L.A., and Bridges, C.M. (2006). A Contingency Approach to Adaptive Selling Behavior and Sales Performance: Selling Situations and Salesperson Characteristics. Journal of Personal Selling and Sales Management, Vol. XXVII(2).

9. Ghozali, I. (2008). Structural Equation Modeling Metode Alternatif dengan Partial Least Square. Edisi 2. Semarang: Badan Penerbit Universitas Diponegoro. 
10. Grizzle, J.W., Zablah, A.R., Brown, T.J., Mowen, J.C., and Lee, J.M. (2008). Synergistic Performance Effects of Employee Customer Orientation and Firm Customer Orientation. Working Paper. Spears School Of Business. Oklahoma State University.

11. Hair, J.F., Hult, G.T.M., Ringle, C.M., and Sarstedt, M. (2014). A Primer On Partial Least Squares Structural Equation Modeling (PLS-SEM). California: SAGE Publications, Inc.

12. Homburg, C., Wieseke, J., and Bornemann, T. (2009). Implementing the Marketing Concept at the Employee-Customer Interface: The Role of Customer Need Knowledge. Journal of Marketing. 73 (July), 64-81.

13. Irianti, N. (2008). Analisis Faktor-Faktor yang Mempengaruhi Adaptivitas Tenaga Penjualan dalam Meningkatkan Kinerja Tenaga Penjualan Pada PT. BPR Bringin Dana Sejahtera Jakarta. Tesis. Universitas Diponegoro Semarang.

14. Keillor, B.D., Parker, R.S., and Pettijohn, C.E. (2000). Relationship-Oriented Characteristics and Individual Salesperson Performance. Journal of Business and Industrial Marketing. 15, No.1. 7-20.

15. Lukas, B. and Ferrell, O.C. (2000). The effect of market orientation on product innovation. Journal of the Academy of Marketing Science. Vol. 28, pp. 239-47.

16. Morgeson, F.P., and DeRue, D.S. (2006). Event Criticality, Urgency, and Duration: Understanding How Events Disrupt Teams and Influence Team Leader Intervention. The Leadership Quarterly, 17:271-287.

17. Park, J., and Holloway, B.B. (2003). Adaptive Selling Behavior Revisited: An Empirical Examination of Learning Orientation, Sales Performance and Job satisfaction. Journal of Personal Selling \& Sales Management. Vol. 23, 3 (Sumer), 239-251.

18. Rentz, J.O., Shepherd, C.D., Taschian, A., Dabholkar, P.A., and Ladd, R.T. (2002). A Measure of Selling Skill: Scale Development and Validation. Journal of Personal Selling and Sales Management. Vol. XXII, No. 1. 13-21.

19. Roman, S., and lacobucci, D. (2010). Antecedents and Consequences of Adaptive Selling Confidence and Behavior: A Dyadic Analysis of Salespeople and Their Customers. Journal of The Academy Marketing Science. 38:363-382.

20. Rozell, E.J., Pettijohn, C.E. and Parker, R.S. (2003). Customer-oriented selling: exploring the roles of emotional intelligence and organizational commitment. Psychology and Marketing. Vol. 21, pp. 405-24.

21. Srinanda, I.S.I. (2003). Analisis Pengaruh Orientasi Pelanggan, Adaptabilitas, and Orientasi Pelayanan Terhadap Kinerja Tenaga Penjualan: Studi Terapan Pada Manajemen Tenaga Penjualan Industri Jasa Pelayaran di Kota Semarang. Tesis. Universitas Diponegoro Semarang.

22. Stock, R.M., and Hoyer, W.D. (2005). An Attitude-Behavior Model of Salespeople's Customer Orientation. Journal of the Academy of Marketing Science. 33(4): 536-552.

23. Turnley, W.H., and Bolino, M.C. (2001). Achieving Desired Images While Avoiding Undesired Images: Exploring The Role of Self-Monitoring in Impression Management. Journal of Applied Psychology. Vol. 86(2):351-360.

24. Watson, K.D., Polonsky, M.J., and Hyman, M.R. (2002). Designing Vignette Studies in Marketing. Australasian Marketing Journal, 10(3):41-58.

25. Wilkinson, J.W. (2008). Levels of Sales Leadership Support: An Exploratory Study. Journal of Selling \& Major Account Management. Vol. 8, No. 4:8-22. 